\title{
Nós também temos voz: dinâmicas e movimentos em análise
}

\author{
We also have a voice: dynamics and movements in analysis
}

Raquel Pacheco*

\begin{abstract}
Resumo: Este artigo baseia-se no trabalho de campo desenvolvido durante pesquisa realizada numa escola pública na cidade de Lisboa. Utilizamos o cinema como meio para reflexão sobre a violência, cidadania e juventude. Nossa intenção foi tentar perceber, através de alguns filmes, por um lado o movimento que ocorre quando o cinema de ficção aborda a temática da realidade de crianças e jovens pobres e excluídos, trazendo a vida destes jovens para as telas; por outro lado, a visão que os jovens têm destes filmes, utilizando o cinema como meio para que eles pudessem se sentir estimulados para externalizar o que pensam, sentem e veem. Para entendermos o olhar dos jovens, desenvolvemos uma pesquisa etnográfica, durante seis meses, e utilizamos como "campo" uma escola secundária situada dentro da zona urbana de Lisboa. O objetivo dessa investigação foi perceber como os jovens se veem e pensam ser vistos pela sociedade (o que inclui o cinema, as mídias etc.) da qual fazem parte. Foi utilizado como ferramenta de registro de pesquisa, por parte da autora, um "diário de bordo" retratando o dia a dia na escola. A filosofia deste trabalho de campo baseia-se na pedagogia dialética de Paulo Freire. É através do diálogo problematizante desenvolvido principalmente após a exibição de filmes, nas aulas e nos encontros, de uma maneira geral, que estimulamos o questionamento e a problematização, e a partir de questões, opiniões e ideias realizamos um vídeo. Através da educação para, com e sobre as mídias, utilizamos conceitos de comunicação, educação e participação, trabalhando temáticas relacionadas ao dia a dia destes jovens. O produto final deste projeto foi um documentário em que os alunos foram os protagonistas em todas as etapas de realização: da pré-produção à finalização.
\end{abstract}

Palavras-chave: Mídia educação. Jovens. Pesquisa etnográfica.

Abstract: This article is based on fieldwork carried out during research conducted in a public school in Lisbon. Cinema is used as a medium for reflection on violence, citizenship and youth. First of all, the article tries to understand through some films the movement that happens when fictional cinema attempts, through the theme of the reality of poor, excluded children and young people, to bring the lives of these young people to the screen and secondly, the view that young people have of these films and how to use cinema as a medium by which they might feel stimulated to externalize what they think, feel and see. In order to see through the eyes of young people an ethnographic research was developed for six months and used as the "field of study" a secondary school situated within the urban area of Lisbon. The aim of this research was to understand how young people see themselves and how they think they are seen by society (which includes the cinema, the media, etc.) of which they are a part. The author used a research notebook diary depicting daily life at the school as a research tool. The philosophy of this field work is based on the dialectical pedagogy of Paulo Freire. Using problematizing dialogue, mainly developed after the showing of films and during classes and meetings, questioning and problematization was encouraged; and through questions opinions and ideas a video was produced. Utilizing education 'for', 'with' and 'about' the media concepts of communication, education and participation were used,

\footnotetext{
* Mestre e doutoranda em Ciências da Comunicação, Estudo dos Media e do Jornalismo pela Universidade Nova de Lisboa. E-mail: <raquel.pacheco@gmail.com>.
} 
working with issues related to the daily lives of these young people. The final product of this project was a documentary, in which the students were involved in all stages of execution, from pre-production to completion.

Keywords: Media education. Young people. Ethnographic research.

\section{Espaço escolar: possibilidades e constrangimentos}

O tablado da sala de aula parece que acentua a distância entre alunos e professores, os inferiores (que ficam lá embaixo) e os superiores (que ficam lá em cima). Preferi não usar o tablado, coloquei-me no mesmo nível dos alunos, pois não estava ali como professora ou doutora, como apresentou-me, gentilmente, a professora Sônia. Estava ali como alguém que tinha uma ideia, um projecto e que queria propor àqueles rapazes um trabalho em grupo. Onde ninguém seria mais, ou menos, que ninguém, onde todos fossem importantes. Iríamos trocar experiências, eu com a minha bagagem e cada um deles com a sua própria bagagem. (CUNHA, 2009, p. 152)

A Escola Secundária PM é uma escola com uma "população escolar com bastante problemas”, como nos disse o diretor pedagógico em sua entrevista. O diretor está na escola há 19 anos e acompanhou as mais diversas fases passadas com o sistema educacional português e suas ressonâncias na PM.

\section{A escola}

vai do $7^{\circ}$ ao $12^{\circ}$ ano diurno e noturno, com cursos profissionais, tecnológicos e cursos direcionados para alunos que decidiram alterar o percurso escolar. São cursos de Informática, Eletricidade, Mecânica e Construção Civil.

Como os cursos são mais tecnológicos, compartilhamos nossa opinião com o diretor, que acredita que "este fato pode explicar a escola ter muito mais rapazes que raparigas ${ }^{1}$ ”.

A turma com a qual trabalhamos era da área de informática e composta apenas por rapazes. A ausência de meninas fez com que o projeto fosse "virando-se" naturalmente para o universo masculino. Os assuntos abordados ao longo desta investigação-ação foram muito mais de caráter masculino, com suas opiniões e modi operandi. Em entrevista, o diretor diz:

A escola tem capacidade para 1.000 alunos, mas com os anos foi perdendo alunos. Esta escola é para alunos que têm vocação para cursos tecnológicos. Os alunos que querem ir para a Universidade não vêm para esse tipo de escola. O encaminhamento psicológico encaminha alunos com insucesso para os cursos técnicos. Os alunos normalmente são selecionados para esses cursos de acordo com os serviços de psicologia.

Fica claro que o grupo de alunos que constituem a PM são em sua maioria jovens com um percurso de insucesso escolar e quando pedimos para o diretor definir o perfil desses alunos, ele responde:

É muito difícil definir os alunos, pois correspondem a um grupo muito heterogêneo. Temos um padrão de aluno que atravessa todas as turmas, que não tem

\footnotetext{
${ }^{1} \mathrm{O}$ Texto foi escrito originalmente na variação linguística de Portugal e transposto para a variação brasileira, porém sempre que possível preservamos algumas expresssões típicas em respeito à fala dos sujeitos.
} 
grandes perspectivas, algumas dificuldades socioeconômicas, falta de hábitos de trabalho. Há alunos fracos que se esforçam e alunos desinteressados que estão na escola como espaço de convívio.

Quando chegamos à escola percebemos um clima tenso, um ambiente pesado, e registramos este ambiente no diário de bordo:

Encontrei uma escola que me pareceu em 'guerra'. Meninos e meninas, ou melhor, jovens enormes gritavam e corriam pelos corredores. Todos com 'piercings', roupas 'da moda'. As meninas com plumas, roupas 'giras'2; os meninos com as cuecas à mostra, bonés, gel no cabelo. Tênis parecidos, calças parecidas; tive mesmo a impressão que o ‘fashion' e ousado era o 'uniforme'. Funcionários irritados com a conduta, roupas e 'trejeitos' dos alunos, foi o outro lado da moeda que vi. Olhavam ‘torto’ para os jovens, chamavam a atenção e eles cada vez mais agitados. Um exemplo é a senhora, auxiliar da cantina, que virou-se, sem mais nem menos, para um rapaz e sem nenhum respeito, perguntou-lhe por que andava com as cuecas à mostra e disse que se fosse ela, responsável, não permitiria. (CUNHA, 2009, p. 138)

Meses mais tarde, quando tivemos a oportunidade de realizar uma entrevista com o diretor, pudemos perceber alguns dos motivos para essa suposta "guerra” que pudemos presenciar no início do ano letivo de 2006/2007 na PM. O diretor sublinha que

[...] a escola até o ano passado tinha 260 alunos, este ano passamos para 460 alunos. O clima no início deste ano estava muito difícil, mas agora está melhor. Tivemos dificuldade de controle nos espaços fora da sala. Isso melhorou à medida que fomos identificando os alunos. Há um

\footnotetext{
${ }^{2}$ Em Portugal esta é uma gíria que quer dizer 'legal', 'transada', 'bacana'.
}

compromisso em descobrir os problemas e há a investigação dos problemas.

Realmente, com o passar dos meses o ambiente acalmou-se consideravelmente, mas a impressão e o sentimento de que havia sempre algo “errado” eram sempre vivenciados todas as vezes que íamos à instituição.

A “guerra” dos alunos contra professores e funcionários ou também podemos dizer a "guerra” dos funcionários e professores contra os alunos foi algo que nos incomodou, constrangeu e nos fez questionar sobre a eficiência daquele sistema escolar (o que engloba metodologia de educação, conceitos e prioridades).

Quando acabei de falar com a Sônia, percebi que os rapazes debruçavam-se nas janelas e assobiavam e gritavam para alguma coisa ou alguém lá embaixo. Entretanto, a professora não quis saber do que se tratava, gritou para os rapazes sentarem-se em seus lugares e disse que tinha uma coisa que eles deviam saber; eles pouca atenção deram a ela que, irritada, virou-se e disse-me: 'Eles não sabem nada mesmo!' (CUNHA, 2009, p. 146)

Nesta concepção, professores, instrutores e comunicadores, ou seja, os educadores, adotam atitudes de quem conhece os procedimentos corretos e os valores adequados, e a partir daí determinam as formas de conduta dos demais. Essa impressão do conceito de professor “detentor" de toda a sabedoria existente dentro da sala de aula foi a postura que vi durante todo meu trabalho na PM. Não era só uma postura dos professores, mas também dos funcionários. A passagem que cito a seguir ilustra essa relação conflituosa e de "medição" de poder entre adultos - protagonizado pelos professores e funcionários - e jovens - protagonizado pelos alunos - dentro deste ambiente escolar: 
A secretária preencheu os papéis referentes à burocracia para dar entrada naquele material que havia sido retirado de um aluno inconveniente. Mas na hora de dizer o nome daquilo, não soube explicar, então perguntou-nos e a professora Sônia respondeu logo: 'instrumento de tortura'; e explicou-se: 'Para um professor tentando dar aula, isso é um instrumento de tortura.' A secretária adorou a nomenclatura e pareceu-me que de fato tinha escrito aquilo. (CUNHA, 2009, p. 152)

O estereótipo de uma juventude "ameaçadora” era o que circulava pela escola. Esse estereótipo estava vivo e podia ser visto das mais variadas formas possíveis. Ninguém fazia questão de escondê-lo, pelo contrário - a ordem do dia era enumerar todas as características dessa juventude perigosa, violenta, insubordinada, desinteressada e ameaçadora.

Podemos ilustrar essa afirmação com alguns excertos das entrevistas aos professores. Quando perguntamos à professora Sônia, de 32 anos, se achava que os jovens de hoje eram violentos, ela respondeu:

São muito violentos na sua maneira de ser, são naturalmente agressivos. Se calhar é porque não são felizes, faltam perspectivas e isto os torna assim muito agressivos. A forma de eles protestarem é a agressividade.

Para os jovens de hoje existe "uma falta de interesse por tudo, não só pelas atividades, mas com tudo. Não têm gosto em conhecer, nem interesse”.

E quando perguntamos se a professora achava que existia violência na escola ela respondeu: "Há muita. Física, verbal, imensa. Por parte dos alunos, os professores são demasiado pacíficos. Se não fosse isso já tinham posto fim nesta onda de violência.” Segundo Sônia os alunos que frequentavam a escola eram “mal-educados, malformados, agressivos, e pouco interessados pelas atividades letivas (pouco ou quase nada)". E a escola era cada vez mais pensada para o aluno, “cada vez mais. Porque tenta se adequar aos horários dos alunos, currículos, outras atividades. É sempre em função deles”.

Nosso projeto foi ministrado durante o horário das aulas de Cidadania da professora Sônia, e assim tivemos acesso a uma de suas aulas. A aula foi sobre racismo e a professora trabalhou o tema a partir de uma matéria de jornal. Após os alunos terem lido o texto, que era compartilhado (um texto para dois alunos, pois não havia fotocópia para todos), começaram a conversar entre si, mas a professora

chamou a atenção dos alunos, com ameaças e arrogância. Disse que aquilo não era uma democracia e que quem mandava ali era ela. Compartilhar com o próximo, a experiência que ler um texto provocava, não cabia ali

pois apesar da leitura ser compartilhada, as ideias eram para ser expressas apenas no momento que ela achasse mais oportuno.

Os alunos, os treinandos, os receptores dos comunicados passam a ser capacitados em função das condutas preconizadas. Logo, os métodos e os procedimentos pedagógicos utilizados são verticais, sem a participação dos alunos, que se transformam em objeto da ação dos educadores - neste caso, da educadora. Estes atuam, fazem os diagnósticos da realidade, avaliam o grau de conhecimento e definem os conteúdos que os alunos devem receber.

O que os alunos pensavam de fato sobre aquele texto e suas ideias acerca do racismo

[...] na realidade nada disso interessava à professora; o que a interessava de fato era a parte do texto em que o jornalista contava que o negro, motorista do transporte, que na verdade era um caminhão, 
dizia: 'No habitáculo ${ }^{3}$ os lugares estão todos ocupados. Mas és branco, não podes viajar nas traseiras. Vamos ver se te conseguimos sentar no habitáculo.' Claro que conseguiu, com certeza um negro foi para trás, para que o jornalista pudesse viajar confortavelmente no habitáculo.

A professora chamou este caso de racismo ao contrário. E perguntou o que eles viam no texto. Diante da confusão dos alunos ela disse: 'Racismo de preto com branco.'

E continuou: 'Viram? Então vocês pensam que só o branco tem atitudes de racismo com o preto. Ahhh, então não é só o branco.' Os meninos pretos mostram-se constrangidos. Aquilo era uma aula de Cidadania aonde em que pretendíamos esclarecer o que era racismo e a partir deste ponto colocarmos uma discussão respeitável, sadia, esclarecedora, onde todos pudessem expor seus pontos de vista, trocando experiência e consequentemente aprender. Ou era uma sessão de acusações e preconceitos? (CUNHA, 2009, p. 147)

Dentro dessa concepção, a aplicação dos métodos de ensino têm sua atenção centrada mais na "matéria” que tem que ser transmitida aos alunos do que no processo social envolvido na educação:

Uma certa altura a professora perguntou aos rapazes se preferiam que ela chamasse pretos ou negros. Aquilo tudo era tão insólito para mim que por alguns momentos tive vontade de me retirar e ir embora mesmo. (CUNHA, 2009, p. 152)

Percebemos que a maneira com que a professora lida com essa juventude “ameaçadora” é através de uma atitude defensiva, que na verdade ela tenta disfarçar mantendo-se “distante” da vida

\footnotetext{
${ }^{3}$ Compartimento fechado de um meio de transporte destinado ao condutor ou aos ocupantes (ex.: habitáculo de um automóvel). (Nota do revisor.)
}

e da realidade daqueles alunos. Atacando, a professora pensa que está a defenderse de uma ameaça que ela acredita existir. “Atacar” aqueles jovens, na verdade, é um mecanismo de defesa. Ela se defende de todo um imaginário, ela se defende desses jovens que não fazem parte da sua classe socioeconômica, desprovidos de cultura (no conceito equivocado desta palavra) e saber (saber este definido pela própria professora). Enquanto vê esses jovens com as lentes do preconceito, deixa escapar importantes dados que poderiam ajudá-la na relação com aqueles alunos.

Bruno, que havia sido o primeiro a chegar na aula, fica na sala para falar comigo. Diz que faz letras de hip hop e me pede para dizer o que penso sobre o racismo para que ele saiba o que ‘deve’ escrever numa música que estava pensando fazer para o vídeo. Digo que ele deve escrever sobre o ponto de vista dele. O que ele pensa, sobre o tema que ele quiser, é sobre isso que deve ser a música.

Na entrevista descobri que Bruno morou muitos anos da sua infância no Gabão, lugar onde se passava o texto trabalhado pela professora na aula passada. Bruno mais do que ninguém poderia ter falado sobre o Gabão e até explicado por que os brancos não podem andar nas traseiras dos transportes. Ele era a pessoa mais indicada para ter falado sobre histórias, racismo e preconceitos daquele lugar. (CUNHA, 2009, p. 163)

Por ver aqueles jovens através de um estereótipo e, consequentemente, por causa disto, utilizar um mecanismo de defesa que a afaste de qualquer contato mais próximo e qualquer tipo de diálogo e troca de saber com esses jovens é que a professora Sônia perdeu a oportunidade de transformar aquela aula em um verdadeiro espaço democrático, onde através do diálogo problematizante 
professora e alunos pudessem fazer descobertas, conhecer novos conceitos, territórios e expandir horizontes. Por isso a educação está longe de atingir os objetivos que se propõe, pois é “comunicada” de uma forma homogênea.

Percebi que eles (os alunos) não se sentiam fazendo parte daquilo, de um todo, nem daquela escola e muito menos daquela aula de suposta Cidadania. Senti que professores, funcionários e alunos corriam em linhas paralelas. (CUNHA, 2009, p. 148)

Essa postura autoritária, arrogante e distante do professor é verbalizada pelo diretor quando responde em sua entrevista que "há professores que acham que a autoridade consegue-se com a distância”. Mas não generaliza o que diz, pois acredita que existem bons professores na PM, apesar de serem minoria.

Os alunos eram em grande parte filhos de imigrantes, num país que de um dia para o outro começou a receber pessoas e informações de toda parte do mundo, da China aos Estados Unidos, do Brasil ao Leste Europeu. E junto com esta abertura seguiram-se os apelos consumistas do capitalismo, desejo de ter, que para o sistema atual acompanha o existir (tenho logo existo), os apelos da publicidade e consequentemente uma certa 'manipulação' mediática, com todo seu poder de domínio e fascinação sobre crianças, jovens e também adultos. (CUNHA, 2009, p. 161)

Mas o estereótipo da juventude como “estilo de vida” também existe na escola - na verdade coexiste com o da juventude "ameaçadora”. É na escola PM que o programa televisivo Morangos com açúcar, endereçado à juventude portuguesa, grava algumas cenas de seus jovens "politicamente corretos" (às vezes nem tanto), quando estes estão na escola.
Se por um lado os alunos da PM são em grande parte negros, filhos de imigrantes e do proletariado português, os Morangos mostram nesta mesma escola jovens em sua maioria brancos, de boas famílias, sem muitas preocupações ou problemas, além de seus relacionamentos e o consumismo fútil.

O refeitório estava vazio, mas duas pessoas da produção dos Morangos estavam preparando umas mesas, com toalhas, talheres, comida e sobremesa especial para a equipa de gravação. Tudo muito bem-arranjado e com bom aspecto, muito diferente da 'nossa' parte do refeitório e da comida que comíamos. (CUNHA, 2009, p. 163)

Essa é - sem querer ser - uma boa metáfora para compararmos os Morangos com açúcar e toda sua simbologia de uma juventude vista pelas lentes da publicidade, dos jovens bem vestidos, espertos, agradáveis e a juventude da PM, que era exatamente o oposto de tudo isto. Enquanto a equipa dos Morangos comia uma deliciosa refeição, arrumada no mesmo refeitório dos alunos da escola, mas num lugar mais exclusivo servido com toalhas e talheres bonitos, os alunos pagavam para comer uma comida mal preparada e nutricionalmente muito fraca. Seguem abaixo alguns comentários dos alunos sobre a presença dos Morangos na PM:

Bruno perguntou 'o que era aquele arroz’. Ele não comeu nada da comida, só o iogurte.

Eu, em tom de brincadeira, falei que nós íamos comer nas mesas da equipa dos Morangos. Todos riram, Jorge riu, sem me encarar, olhando para o lado, meio para baixo. Bruno confirmou e disse para o primo, quando este perguntou se ele não ia comer nada, que ia comer 'lá' na mesa 'deles' [da equipa dos Morangos]. 
Franco disse para Bruno comer pois muita gente passava fome e que até aquela comida iria fazer falta a alguém, com um tom imitando 'os adultos' a falar.

\section{E complementou:}

- Na sua terra, Bruno, muita gente quer essa comida para comer. E não só na sua terra não, na minha e na do Jorge também. Lá o povo morre de fome.

- Morre de fome nada! Passa fome, até passa, mas morrer de fome, num morre não. Nunca vi - disse zangado Bruno, recriminando Franco por unir-se ao coro dos brancos que só sabem falar mal da África. (CUNHA, 2009, p. 163)

A realidade daqueles rapazes está muito distante da realidade dos jovens dos Morangos ou dos belos jovens da publicidade; eles têm consciência disso, e até um certo ressentimento. Ressentimento por não se verem na televisão e muito menos na publicidade, ou por só se verem nas notícias "ruins" dos noticiários da televisão - definitivamente aqueles são dois mundos muito distantes.

Aluno: A realidade não é os Morangos.

Eu: É, os Morangos não são a realidade.

Sônia: Você assiste aos Morangos?

Eu: Só assisti poucas vezes, para a investigação.

Eu: Que imagem vocês querem passar dos jovens hoje em Portugal?

Rafael: Tocou na ferida; a nossa imagem, a nossa realidade? Isso não pode passar, porque fica censurado. [Olhou para a professora Sônia, que foi a imagem da censura durante todo o debate.] (CUNHA, 2009, p. 164)

Mas os Morangos fazem parte da juventude idealizada pela professora Sônia e por muitas outras pessoas. Sônia não consegue perceber o motivo por estarmos a "falar mal” dos Morangos. Seu tom de censura, sua postura contra toda aquela reflexão, aquele questionamento, as opiniões dos alunos..

A postura do professor no papel de censor esteve presente em todas as fases deste trabalho de campo. Os alunos perceberam o constrangimento que os professores causavam. Sabiam que não podiam dizer tudo que pensavam, sentiamse (e verbalizavam isso) como se estivessem sendo vigiados e comparavam a escola a um depósito de jovens - era como se estivessem ali só para “matar” o tempo.

Bruno sugere que falemos com o professor que dá aula após a de Cidadania, pois além dos 45 minutos da aula da Vânia teríamos também mais um tempo para ver o filme e fazer o debate.

Jorge olha para mim e complementa: 'Nós não fazemos nada na aula dele mesmo. Ficamos lá só a perder tempo.' (CUNHA, 2009, p. 146)

Perder tempo, matar o tempo. Existe a necessidade de os jovens usarem melhor o seu tempo. Menos horas em frente à televisão e à Internet, menos tempo livre para pensar em coisas pouco produtivas, principalmente aqueles que encontram-se quase "à margem”. Mas não existe um interesse em que esses jovens empreguem seu tempo em coisas realmente produtivas que realmente lhes interesse.

\footnotetext{
- E essa questão de Portugal ter uma das maiores cargas horárias na escola? Só em Portugal a aula vai das 8 h30 da manhã às $18 \mathrm{~h} 30$ da noite. Em Angola não é assim, no Brasil não é assim, em Espanha não é assim, nem na Bulgária, que tem as pessoas mais inteligentes, também não é assim - diz Francisco, querendo debater o assunto.
} 
- É para manter o controle sobre os jovens. Estamos aqui para eles nos controlarem diz Bruno.

Todos falam ao mesmo tempo, todos concordam entre si, a carga horária é excessiva e não contribui para um bom desempenho escolar. Digo que percebi que eles ficam muito cansados no final do dia.

- Não é só cansado, não. Não temos tempo para praticar um esporte, temos aulas pouco interessantes - fala um aluno.

- Ficamos saturados - diz Manuel.

- Não podemos sair com os amigos, nem ficar direito com a família, muito menos praticar um esporte, não temos tempo livre - completa Paulo. (CUNHA, 2009, p. 147)

De fato o horário escolar, em Portugal, normalmente é das $8 \mathrm{~h} 30$ às 16h30, o que é bastante, mas no caso de cursos técnicos ou profissionalizantes este horário pode tornar-se mais alargado, como é o caso da turma em que trabalhamos.

Segundo Adorno e Horkheimer (1985, p. 103) o tempo livre é acorrentado ao tempo "não livre".

Esta oposição, a relação em que ela se apresenta, imprimi-lhe traços essenciais. Além do mais, muito mais fundamentalmente, o tempo livre dependerá da situação geral da sociedade. Nem em seu trabalho, nem em sua consciência dispõem de si mesmas com real liberdade.

A escola é reconhecida pelos próprios alunos como um lugar que "tem tudo" para ser acolhedora, interessante, agradável. Nas entrevistas do vídeo quase todos reconhecem a escola como um lugar que investe nos jovens e que por isso eles também devem investir (frequentando-a) para um dia "serem alguém na vida”. Mas a escola está longe de ser um espaço democrático, um lugar agradável ou ter um ambiente de respeito mútuo.

O espaço físico da escola é enorme, corredores cinza e frios. Senti uma total falta de aconchego naqueles espaços impessoais, tristes. Mas, por outro lado, senti que ali era o lugar certo para aqueles meninos, que a ideia dos ‘cursos' era ótima, que aquele espaço maravilhoso poderia ganhar vida e cor e que tudo aquilo parecia um grande mal-entendido. (CUNHA, 2009, p. 142)

\section{Lugares dos jovens: pontos de partida, de viragem e de chegada}

- O que você gostaria de ver na televisão? Depois de um certo tempo para pensar, a criança respondeu para a pesquisadora:

- Eu!!!

(OROFINO, 2005 p. 95)

\section{Pontos de partida}

Senti a diferença de tratamento quando questionei Pedro, rapaz negro, que apesar de não ter ido direto para a sala, como deveria ser feito, me respondeu com educação e respeito. Rafael, rapaz branco que seguiu para a sala como mandam as 'regras’, foi grosseiro e sarcástico. Durante a aula iria perceber que essas características eram traços marcantes naqueles dois rapazes.

Sublinho a distinção entre as duas raças, porque é claro e gritante como são os brancos para um lado e negros para o outro. (CUNHA, 2009, p. 142) 
A passagem que acabamos de citar simboliza o primeiro contato que tivemos com os alunos da turma que iríamos trabalhar. A segregação racial (iremos falar sobre este tema mais adiante) foi algo que muito nos marcou nos primeiros encontros com os alunos. Talvez porque tenhamos vindo de um país (Brasil) onde esse tipo de segregação é cada vez menor, principalmente nas classes econômicas mais baixas.

O primeiro encontro foi marcado por muita desconfiança, "me apresentei, apresentei o projecto, falei sobre a importância deles estarem, realmente, disponíveis para aquele trabalho. Falei sobre o protagonismo deles em todas as etapas de produção e execução do vídeo e sobre a necessidade de um respeito mutuo."

No início, seus rostos eram de desinteresse, como se esta não passasse de mais uma actividade, entre tantas outras, que não os interessava. Depois o olhar era de desconfiança, será que alguém ali era capaz de dar voz a eles? E então, percebi que o silêncio tornou-se geral e que suas mentes pensavam sobre aquela proposta e seus rostos, finalmente, começaram a realçar um interesse e vislumbrar (quem sabe?) uma oportunidade. (CUNHA, 2009, p. 142)

Nossa percepção sobre este assunto foi confirmada mais tarde com o resultado das entrevistas finais que foram realizadas após a exibição do vídeo na escola. A seguir, alguns excertos acerca do que os rapazes pensaram do projeto nos primeiros encontros:

No início foi assim uma brincadeira, não tinha levado a sério, depois comecei a assumir as minhas responsabilidades e em seguida quis fazer o vídeo até o fim. Estou contente e feliz pelo que desenvolvi e por termos conseguido alcançar nossos objetivos. Não sabia o que era, não estava a espera que fosse algo para a gente desenvolver tanto. Não estava a espera. (Nuno)
Uma coisa menos, mais ligeira, menos trabalhosa, que não fosse levada tanto a sério. (Samuel)

Não esperava que resultasse tão bem. Achava que iria dar mais confusão e não organizar tão bem as coisas. (António)

Não me interessei no projeto por uma coisa: achei que fosse ser maçante. (Guilherme)

Achei que era um bom tema, mas achei que o trabalho era como os outros e não me empenhei. Gostei do que vi na televisão e no vídeo e achei que podia ter dado um contributo maior. Uma vontade de ter me empenhado mais. (Jorge). (CUNHA, 2009, p. 178)

Acreditavam ser mais um projeto da escola, algo que não os interessaria, alguma atividade monótona como as aulas que costumavam assistir, onde o professor "deposita" a matéria e eles "recebem" o conteúdo sem questionar, sem dialogar e sem participar. $\mathrm{E}$ a investigadora era mais uma pessoa que estava ali para "tomar-lhes" o tempo com coisas desinteressantes. Essa foi uma grande dificuldade para o desenvolvimento do projeto. Provar para aqueles jovens que o projeto não pertencia à escola, apesar de ser desenvolvido dentro dela; provar que nós não estávamos ali com a postura de um professor ou um doutor. Mostrar as reais intenções daquele projeto que estávamos propondo executar foi uma tarefa bem difícil. O ambiente escolar influenciou muito negativamente o desenrolar do projeto. Apesar de acreditar ser a escola o espaço mais adequado para o trabalho que queríamos desenvolver, aquela escola, naquele formato (o ambiente de censura, desrespeito, desinteresse etc.), com certeza foi um obstáculo para nossa pesquisa.

Apesar dos obstáculos percebia que

todos na escola pareciam estar muito disponíveis para mim, ou melhor, para 
o projeto. Alunos e professores, os dois grupos, me acolhiam com respeito, gentileza e atenção. (CUNHA, 2009, p. 154)

A presença constante dos professores sempre interferindo, criticando, censurando, marcando as diferenças, exercitando preconceitos - sem dúvida este ambiente encontra-se implícito em todo o percurso do projeto e também no resultado do vídeo. Esse ambiente faz parte do mundo daqueles jovens, do seu dia a dia.

“Eram 17 rapazes (acredito que esta seja a melhor maneira de chamá-los), o mais novo com 17 (Júlio) e os mais velhos com 22 (José e Manuel)” (CUNHA, 2009, p. 140) e dos 17 rapazes 11 eram brancos e seis eram negros. Dos 11 brancos, dois moravam em bairros ditos “sociais” (comunidades carentes).

Os negros, por serem na maior parte dos casos imigrantes ou filhos de imigrantes, tinham uma história de vida muito interessante para contar; já os brancos, que eram todos portugueses nascidos cá (no caso específico desta turma), eram mais fechados e tinham uma história de vida sem muita novidade, sem muitas expectativas, pelo menos era isso que me deixavam perceber. (CUNHA, 2009, p. 140)

Mas como toda regra tem sua exceção os dois rapazes brancos que moravam nos bairros sociais eram as exceções do grupo dos brancos,

[...] por estarem muito motivados com o projeto, mas de uma maneira mais englobada. Interessam-se por ver no projeto uma oportunidade de falar sobre questões que os angustiam, que fazem parte das suas vidas, do seu dia a dia; atuam ativamente no decorrer do projeto e têm as mesmas expectativas dos negros. Eles não se encaixam nas características do grupo dos brancos, mas muito mais na dos negros, apesar de também ter algumas das características do grupo dos brancos. Os dois têm várias histórias de violência, descaso policial e social, injustiças e tristezas para contar. Histórias que presenciaram em suas zonas, muitas vezes envolvendo amigos e vizinhos. Os dois retratam, em suas histórias, nos debates e em comentários que fazem em nossos encontros, um Portugal esquecido pelos meios de comunicação, pelo governo e pela população mais favorecida cultural e economicamente.

Os brancos (com exceção de Rafael e António) mostram-se interessados no projeto, pelos filmes e em fazer o vídeo, mas por motivos diferentes dos negros. Para o grupo dos brancos essa experiência é interessante, pela experiência e oportunidade em si. Por terem aulas mais motivantes, por terem a oportunidade de realizar um vídeo, por não estarem nas outras aulas, consideradas 'chatas'. Estes não estão muito interessados no conteúdo do projeto, dos filmes ou dos debates, mas no projeto como uma coisa mais divertida e interessante que as aulas normais e também como uma oportunidade (quem sabe?!) de aparecer na mídia e ter seus 15 segundos de fama. (CUNHA, 2009, p. 159)

Com o avançar dos encontros, os alunos foram adquirindo pouco a pouco confiança e interesse pelo projeto. Uns antes outros depois, cada um a seu tempo, foram interessando-se pelos encontros, pela proposta de trabalho.

Fica claro, através do que dizem e pelo modo como agem que sentem-se sem voz diante da sociedade, que são excluídos e esquecidos. Todo o processo do projeto e a realização do vídeo é visto como uma oportunidade para lidar e trabalhar essas angústias e frustrações e principalmente 
para trazer à tona assuntos considerados ‘tabus' e que não são debatidos com frequência nem profundidade. (CUNHA, 2009, p. 160)

No contexto do desenvolvimento deste trabalho, ambos os sujeitos do processo dialogaram sobre e analisaram criticamente a realidade, situação ou problema (objeto do conhecimento), bem como explicitaram suas percepções e interpretações sobre o tema, ou temas, em discussão.

Mas nem sempre esse processo é internalizado pelos jovens e ficou clara a diferença entre "nós” e os “outros”. Quando aplicamos o questionário sobre violência, que era o tema principal da nossa investigação, eles não se reconheciam fazendo parte de nenhum contexto de violência. Eram sempre "os outros" que eram violentos, que tinham problemas com violência em casa etc. Na hora de definir o significado de violência, todos entendiam que violência poderia ser uma agressão física ou verbal e alguns também falaram da psicológica.

Violência para mim não está só na agressão mas também nas palavras. (José)

É o ato provocado pelas rivalidades e discordância entre as pessoas. Na minha opinião nem sequer devia existir, porque só causa dor e sofrimento entre as pessoas. (Cristiano)

Para mim é algo que pode magoar as pessoas física e psicologicamente. (Jorge)

É quando uma pessoa quebra certos limites e começa a fazer ações hostis, desde a linguagem até o confronto físico entre o agressor e a vítima. (Júlio). (CUNHA, 2009, p. 172)

Eis algumas das passagens que eles acharam mais violentas nos dois filmes:
Foi quando o grupo do Zé Pequeno deu uma arma a um dos miúdos e mandou balear o outro rapaz. (Francisco)

A maneira como puniam os miúdos que roubavam dentro da favela e a maneira como tentaram (o Cenoura e o Zé Pequeno) ser donos de todas as bocas. (António)

Foi como a polícia lidava com o grupo do Tó e a maneira como abandonaram o Pantera e o Tó. (António)

Foi o roubo na ourivesaria, em que o Pantera é baleado pelo guarda noturno. Penso que está foi a cena mais violenta, pois não há muitas cenas de violência. (Cristiano). (CUNHA, 2009, p. 171)

Mas disseram não ver nenhum tipo de violência dentro de casa e tratavam como acontecimentos "naturais" os atos de violência em que se encontravam envolvidos, como algo que faz parte da vida...

Já participei de uma luta de escola como qualquer miúdo (mas isso já foi há alguns aninhos). Nos últimos tempos não. (Francisco)

Já na zona da Damaia, na minha antiga escola, houve problemas com outras escolas, por haver pessoas racistas envolvidas, na altura também me envolvi. (José)

Não, nunca participei. (Bruno)

Eu já participei em conflitos de jovens que vão para a festa e depois se chateiam, e a solução para eles é utilizar as armas. (Nuno)

Já participei de várias situações de violência desde lutas de escola até lutas de rua, mas nada que valha a pena descrever pois foram coisas banais. (Pedro)

Sim, durante um jogo de futebol. Um jogador da equipe adversária partiu para a violência, então me defendi replicando. (Joaquim) 
Sim, ainda na terça-feira eu e mais dois amigos fomos abordados por dois indivíduos, um de raça negra e um branco, que disseram que iam nos afanhar [sic]. (Vasco). (CUNHA, 2009, p. 170)

\section{Pontos de virada}

O ponto de virada é marcado pelos episódios quando os jovens começam a sentir o projeto. Após os primeiros encontros, as entrevistas, começamos o trabalho de assistir e debater os filmes, a sessão com o realizador do Zona J, Leonel Vieira, a preparação do vídeo, o roteiro etc.

É certo que qualquer terreno, qualquer paisagem, se apresenta, à primeira vista, como uma desordem imensa que nos deixa à vontade para escolhermos o sentido que quisermos dar-lhe. (PAIS, 2003, p. 90)

Seguindo esta afirmação de Machado Pais, foi neste momento do projeto que os alunos começaram a acrescentar suas contribuições, construindo junto com a coordenadora o desenrolar das aulas, ou melhor, dos encontros.

Nosso maior interesse era trabalhar e pesquisar a questão da violência, o que esses jovens pensam sobre o tema, como agem e até que ponto eram vítimas ou agressores. Mas a violência com o passar dos encontros transformou-se em apenas mais um tema. Os rapazes estavam interessados em debater assuntos mais abrangentes. Aproveitaram aquele espaço de debate, reflexão e discussão para colocar questões das mais variadas ordens.

Ao adotar a estratégia etnográfica, fazia um esforço deliberado para não me deixar afetar por hipóteses de partida e interrogações de natureza problemática que tinham estado na origem da investigação.
Era um mero curioso desinteressado, ou melhor, apenas interessado em descobrir, na medida do possível, as bússolas cognitivas segundo as quais os jovens davam norte aos seus cotidianos. (PAIS, 2003, p. 89)

No campo, nos sentimos muitas vezes como um camaleão, pelo modo de nos vestir, de falar e até a música que ouvimos.

Muitas vezes percebemos que as palavras que os jovens transmitiam ao primeiro olhar pareciam sem significado e só mais tarde é que descobrimos seu verdadeiro sentido. E foi nesse exercício de nos deixar conduzir que conseguimos dialogar e problematizar questões que talvez, a princípio, não fazia parte do nosso roteiro de investigação. O tema do suposto e famoso "arrastão na praia de Carcavelos”, por exemplo, surgiu em nossos debates como muitos outros, por interesse dos alunos.

Henrique fala sobre o arrastão. A cobertura dada pela mídia ao Arrastão de Carcavelos.

Henrique: Eu estava na praia, foi uma pequena confusão, por causa da polícia, com meia dúzia de rapazes.

Francisco: Fui à praia neste dia e nunca vi tanto preto junto, eu disse: 'Vou-me embora.’ Não via nada, disse a minha mãe que nunca vi tanto preto junto, tudo preto a dançar.

Rafael: Os policiais não gostam de ver os pretos a dançar.

Sônia: Que mentira..... (CUNHA, 2009, p. 157)

Neste sentido, segue o início do diálogo sobre o filme Cidade de Deus após sua exibição:

Eu: Manuel, sobre o que fala o filme? Do que trata o filme? 
Manuel: O filme é sobre... [pensa] o tiro, as mortes. É sobre as pessoas pobres do Brasil.

Júlio: Penso que não, ele deve ter outras imagens, mas foram essas ruins que ele usou.

Eu: Mas ele não pode realçar o que é bom?

Francisco: Ele não pode realçar o que é bom, o que é bom não interessa. (CUNHA, 2009, p. 157)

Assim como alguns críticos de cinema mundial e milhares de espectadores, os alunos também sentiram-se confusos se afinal o filme corresponderia ou não à realidade das favelas brasileiras, já que o filme realça o que aparece constantemente nos noticiários televisivos quando estes falam sobre o Brasil.

Foi preciso fazer um trabalho reflexivo que envolveu um exaustivo debate para que os alunos pudessem perceber o que de fato "viam" naquele filme e a mensagem que ficava nas entrelinhas do discurso fílmico.

Acham que esse filme [Cidade de Deus] representa a visão de quem? Ele passa uma impressão de realidade? É real ou é uma criação do realizador?

Aluno: Pelo que eu sei é parecido com a realidade.

Outro aluno: É uma criação.

Júlio: Creio que o realizador encarnou as más coisas que acontecem no Brasil e passou para o filme. É o que ele pensa do Brasil.

Eu duvido que o realizador tenha feito um estudo muito profundo da Cidade de Deus antes de fazer o filme.

Aluno: Esse filme tem uma ponta de documentário.

Aluno: Ele deve ter ouvido as pessoas que lá estiveram.
Aluno: Ele deve ter pegado as histórias e exagerou.

Aluno: Ele não quis mostrar que aquilo é o dia a dia da favela, mostrou o fato da guerra do tráfico.

Aluno: É uma história e não o dia a dia.

Eu: Isso ficou claro para vocês, né?

Eu: Alguma coisa ali é real, mas não tudo. (CUNHA, 2009, p. 163)

A concepção de educação utilizada no contexto desta pesquisa empírica não pretendeu "educar" mediante mera transmissão ou simples difusão. Nós nos baseamos no paradigma de que o conhecimento se gera ou se recria no diálogo ou na comunicação entre sujeitos, desaparecendo a relação tradicional educador/aluno. Ambos fomos educadores/ educandos simultaneamente, educando-nos reciprocamente no processo de relacionamento humano, no debate, na problematização, na ação criadora e na busca conjunta de soluções para os problemas da realidade que desejávamos transformar.

Enquanto o filme Cidade de Deus causou uma discussão mais "distante" e fora da realidade daqueles jovens "portugueses", o Zona $J$ tocou em alguns pontos que realmente fizeram bastante sentido para eles e contribui para uma discussão mais voltada para a realidade e dia a dia daqueles jovens.

Os grupos, hoje em dia, não são mais divididos tanto por raça, eles dividem-se por modo de vestir - diz Rafael.

As pessoas roubam pela adrenalina de roubar - fala Júlio.

O filme está um bocado desatualizado, pois é um filme de 1998 - diz o Rafael.

Muita coisa mudou de lá para cá - diz outro aluno. 
Hoje em dia há mais roubos na rua Rafael.

As pessoas querem que seu bairro seja o maior - diz um aluno.

O maior como? - pergunto.

As pessoas querem morar num bairro bom e para um bairro ser um bom bairro tem que ter movimento. Movimento é o quê? Tráfico, armas, drogas para ele ser forte diz Rafael. (CUNHA, 2009, p. 155)

O Zona $J$ pode não corresponder de fato à realidade deste novo século, mas trouxe à tona assuntos que os alunos vivenciam na sua realidade. “O racismo está dentro da sociedade, já está nas decisões e no modo das pessoas verem as coisas - fala um aluno.” (CUNHA, 2009, p. 151).

Aproveitamos o diálogo sobre racismo e colocamos o assunto voltado para o que vemos concretamente dentro do contexto daquela turma:

Uma coisa que reparei é que nesta turma e mesmo aqui na escola, o grupo dos pretos e o grupo dos brancos quase não se misturam. Comecei a chamar assim, quando percebi que na turma eram os pretos para um lado e os brancos para o outro, aí comecei a ter que nomear assim, 'brancos' e 'negros'.

Essa é minha análise em relação a vocês; quando tenho que escrever algo em relação às aulas, escrevo: 'o grupo dos negros’ ou o 'grupo dos brancos'. Não que eu seja racista ou qualquer coisa assim, mas vocês se dividiram assim e assim fica mais fácil para eu explicar. Hoje está mais misturado, mas normalmente vocês estão separados por cor, o António é um branco que ainda vai para o 'grupo dos negros'.

Percebi também, continuo, que os negros estão sempre com as camisas de malha e usam capuz. O brancos não, vestem-se diferente, o António e o Cristiano é que usam sempre os gorros. Hoje, por sinal, vocês estão muito mais misturados. Acho isso ótimo. (CUNHA, 2009, p. 163)

Neste caso o papel do "coordenador" deve ser considerado como "agente de mudança”, ou seja, apenas um facilitador no processo de aprendizagem e transformação daqueles jovens. O debate sobre racismo continua e de uma maneira bem diferente do que presenciamos durante a aula de Cidadania da professora Sônia.

Jorge: Os canais nem para arranjar figurantes negros. Nem para ser figurante.

Sônia: Isso é mentira, há, há.

Sônia: Não há racismo nada. Vocês exageram.

No momento que começamos a falar sobre racismo, o Rafael saiu do 'lado' dos brancos e disse que não queria ser racista e foi para o 'lado' dos negros [não havia sido feito nenhum comentário a esse respeito, foi uma atitude e observação dele, só dele]. (CUNHA, 2009, p. 162)

É mediante a participação que se exercita a reflexão, o raciocínio, a inteligência, a imaginação e a criatividade. Assim, conseguimos chegar à "comunicação dialógica”, essência da educação, da qual nos fala Paulo Freire (200 6).Através do diálogo, “instrumento” básico desta "comunicação", partimos do particular para o geral, do individual ao coletivo, do percebido ao não percebido, do simples ao complexo, permitindo a abordagem das situações particulares, individuais, imediatas, percebidas num contexto social, econômico e político mais amplo. Assim os alunos puderam entender, compreender e refletir, de certa forma, a realidade global, com seus reais problemas e suas causas mais profundas. 
Acordamos saímos da porta para fora, está ali toda gente, em volta da fogueira, a pé, estão a rir, vão fumar, depois vão almoçar na casa de um, vão jogar Playstation, depois vão para a rua, falam-se ao telemóvel, vão sair à noite... dá vontade de fazer mais alguma coisa? - fala Rafael. (CUNHA, 2009, p. 167)

Rafael quase não frequentava a escola. Como ele mesmo disse, trocar a posição confortável que ele pode vivenciar com os amigos pelos dias enfadonhos na escola é uma troca ou uma escolha praticamente sem sentido. Rafael levava quase duas horas de transporte para ir de casa até a escola. Levava uma vida no limite entre a "margem" e a escola, mas nos dias dos encontros do projeto lá estava Rafael, sempre assíduo e participativo. Ao meu ver um ótimo aluno, inteligente, foi o primeiro a perceber o que pretendíamos com o projeto e com o vídeo. Mas infelizmente a escola não correspondia a suas expectativas e assim que a edição do vídeo acabou abandonou a PM para só lá voltar no dia da exibição do vídeo.

Buckingham e Block (2007) destacam a importância da audiência e como a percepção de uma audiência real pode ajudar os jovens a conceituar o produto terminado e avaliar o seu próprio trabalho. Percebemos essa afirmação ao presenciarmos a mudança de comportamento em alguns membros da turma quando souberam que um programa de televisão (PICA, RTP2) iria fazer uma espécie de making off dos dias de gravação do vídeo.

Não esperava assim nada que passasse na televisão, que tivesse uma importância tão grande, pensei que fosse um trabalho normal. (Jorge)

Teve um bom resultado, tanto para quem participou como para quem vai assistir. Acho que vai dar uma boa imagem. (António). (CUNHA, 2009, p. 173)
Outro dado importante que contribuiu para que os alunos acreditassem mais no projeto foi a presença do diretor do filme, Leonel Vieira. Depois de assistirem ao Zona $J$, os alunos debateram o filme entre si e mais tarde puderam conversar sobre o filme com o próprio diretor. Leonel Vieira falou sobre como foi fazer o filme, os processos de produção etc. Os alunos puderam trocar ideias, expor suas dúvidas e opiniões diretamente com o próprio diretor.

Chega a turma, todos vêm cumprimentar Leonel, que está sentado na cadeira. Dão a mão, um por um, muito simpático. Leonel retribui fazendo comentários e sendo também simpático. Manuel entra, cumprimenta Leonel e diz que não gostou da segunda parte do filme. Fico sem graça, mas Leonel diz que é um ato de inteligência do Manuel, que tinha sido o produtor que o tinha obrigado a fazer aquele final e que ele também não tinha gostado. Para mim o final seria outro - diz Leonel.

Foi um ato antes de tudo de coragem da parte do Manuel. Complementei e disse ao Leonel que tínhamos feito um debate sobre o filme após a exibição e que tínhamos achado que o filme tinha mudado o estilo da metade para o final e que parecia um grande drama nesta segunda parte. (CUNHA, 2009, p. 164)

Podemos considerar que foi no dia que dividimos a turma em equipes de filmagem que realmente aqueles jovens se deram conta que de fato iam fazer um vídeo a sério. Foi nessa fase do projeto que os jovens finalmente tiveram a sensação de empowering, ou seja, conseguiram apropriar-se do projeto. A escolha dos papéis que queriam desempenhar, a importância de cada papel, de cada escolha... e depois a escolha dos tópicos para o roteiro, tudo isso deu poder aos rapazes. Decidir o que fazer do vídeo e como fazê-lo 
transformava aquela turma numa turma especial. Tornaram-se os "artistas" na escola.

Decidimos em conjunto, sempre com a coordenação e as sugestões da investigadora, o desenrolar do vídeo. O que seria, como seria feito e por que faríamos foram assuntos que pensados em conjunto tornaram o grupo mais coeso e mais confiante na capacidade de realizar a tarefa que queríamos.

Um grupo tinha que escolher pessoas dentro da escola para ser entrevistadas; outro grupo fazia a parte "burocrática" do vídeo (a produção); outros tinham que ir para as aulas técnicas de som e câmera. Foram momentos de preparação que seguiriam os três grandes dias, os dias de filmagem. Nessa altura já não viam mais a investigadora como uma professora ou uma doutora, já a viam como uma companheira de trabalho, uma colaboradora, uma educadora. Trocávamos e-mails, telefonemas e mensagens como uma verdadeira equipe de filmagem. A postura dos alunos era de muita responsabilidade, eles sabiam o que queriam e por que estavam fazendo aquilo. Havia uma confiança mútua, principalmente entre os próprios membros do grupo. Estávamos todos mais próximos e tínhamos uma só linguagem.

Nesse tipo de ação supõe-se que o educador tenha como base o "saber acadêmico" e que os educandos tenham um saber adquirido através da socialização e da sua própria experiência de vida. São dois saberes distintos, mas não essencialmente opostos. O "saber acadêmico", ao confrontar-se com o "saber popular”, não objetivará dominá-lo ou a ele se impor. Só assim ambos os sujeitos do processo educativo terão oportunidade de crescer, de desenvolver-se como profissionais, como trabalhadores, como seres humanos e como membros de sua comunidade e da sociedade global.
Para isso, o processo desta pesquisa teve a participação efetiva dos alunos que representaram seus interesses num constante debate onde puderam crescer mutuamente desenvolvendo suas capacidades críticas a respeito da realidade, voltando-se para ações transformadoras. O que, neste caso, mais especificamente, diríamos ser a realização do filme/documentário. "Eu: Quero que vocês pensem sobre a imagem que vocês querem passar e ver, dos jovens de Portugal, no vídeo.” (CUNHA, 2009, p. 170).

\section{Pontos de chegada: nós também temos voz}

A gente descobre que o cinema não muda a realidade, mas muda a maneira de você ver a realidade.

O cinema não é uma reprodução do mundo, mas a reprodução da relação de alguém com o mundo.

(Cacá Diegues, Jornal do Brasil, 2006)

Os dias de filmagem não fazem parte das anotações do diário de bordo. O que vamos analisar como pontos de chegada é o resultado/consequência (se é que estas são as melhores palavras...) dos quatro meses de trabalho com os jovens. Ou seja, vamos analisar desde os dias de gravação (dois na escola e um em externa) até o visionamento do vídeo pelos alunos, utilizando alguns excertos da entrevista final.

Após muitos debates, discussões, encontros e desencontros, lá estávamos nós "prontos" para finalmente realizar o documentário. Na verdade, todos sabíamos das nossas dificuldades e limitações. O próprio professor Rodrigo disse em sua entrevista que "se for como de costume" o projeto "vai ficar ao meio" e depois complementou: 
“Mas não pode...” Rodrigo era um professor com uma especialização mais voltada para a área técnica, e entre outras atividades era responsável pelos equipamentos de vídeo e tudo que se relacionava à área do audiovisual na escola. Foi o professor Rodrigo quem deu as aulas práticas de som e câmera para os alunos. Confessou-nos, logo assim que conversamos sobre a proposta do projeto, que nunca tinha conseguido terminar um vídeo na PM.

Percebíamos que nem todos os membros do projeto tiveram o mesmo empowering. Paulo, um aluno da turma, nos disse na entrevista final que participar do projeto não tinha feito a menor diferença para ele: "Não. Não me fez diferença. Participar ou não participar não fez a menor diferença."

Durante a maior parte do processo do projeto, Paulo agia muito mais como um espectador dos acontecimentos do que como alguém que estava a participar e fazer parte do processo em si. Percebemos que essa era a postura deste rapaz diante da escola, do grupo e da vida de uma maneira geral. Tivemos essa percepção durante o tempo que convivemos com ele e pudemos observar essa característica mais profundamente nas entrevistas, nas respostas que ele dava durante as conversas etc.

Mas os rapazes em sua maioria estavam integrados, muito participativos e interessados; percebíamos que se sentiam parte do projeto e tinham consciência da importância de seus protagonismos.

Na manhã do primeiro dia de filmagem estávamos todos meio sem saber por onde começar. O desejo de ter voz estaria realmente internalizado naqueles rapazes? Afinal, queriam ou não queriam ter voz? Necessitavam aqueles jovens, de fato, ter voz?

Nesse sentido, percebemos que a maior parte daqueles jovens nunca tinha pensado sobre esse assunto. Não sabiam que podiam ter voz, ou que tinham direito a isto. Como nunca pensaram sobre o assunto, ter voz ou não ter voz, definitivamente não fazia parte das suas listas de desejo (pelo menos para o grupo dos brancos, com as duas exceções). O grupo dos negros já haviam deixado claro durante todo aquele trabalho que sentiam-se sem voz e que queriam tê-la - por isso provavelmente os negros faziam parte de grupos de hip hop, escreviam poesia e faziam rap.

Dar voz aos jovens, suas opiniões, se eles devem ou não ser ouvidos, se eles têm ou não direito a ter direitos são assuntos que não são debatidos normalmente na televisão, pelo menos não nos programas que eles assistem. Não é debatido na Internet, pelo menos não nos sites por onde eles navegam. Não é assunto escolar. Esse debate não chega até os jovens, muito menos até os jovens das classes socioeconômicas que participaram desta investigação.

Ter voz era algo novo para eles. Tirando os nossos encontros, poucos deles tinham parado para pensar sobre esse assunto em outra oportunidade. Não podemos fazer com que uma pessoa sinta necessidade ou falta de algo que não conhece, que não sabe nem que existe.

Nas primeiras horas da nossa estreia como equipe de filmagem foi um duro processo de adaptação. Aqueles rapazes nunca tinham passado por aquela experiência antes, estavam a representar papéis que conheceram durante os encontros do projeto. Uns demoraram mais que outros para entrar de fato nos seus papéis. As coisas não fluíram com tanta facilidade como a princípio fantasiávamos que aconteceria. O que queremos dizer é que algumas questões - como o que perguntar, o que de fato queremos saber e falar, sobre o que estamos falando, que imagem 
nós queremos construir através deste veículo que chamamos de filme - estavam presentes, vivas, e ecoavam nos diálogos entre o grupo na manhã do primeiro dia de filmagem. O conteúdo e a abordagem do documentário surgiram com muito mais dificuldade que a representação dos papéis que cada um estava a representar.

Mas com o passar do dia tudo foi se organizando e arrumando, já havíamos falado exaustivamente sobre como seria aquela experiência. Todos tinham sanado suas dúvidas e conversávamos sobre as outras muitas dúvidas que ainda surgiam durante as filmagens. Para nossa surpresa aqueles jovens foram se encaixando nos seus papéis ou os papéis foram se encaixando nos jovens.

A equipe dos câmeras escolhia com os diretores a melhor posição para o equipamento e ficava em torno da câmera aprontando tudo, arrumando, vendo enquadramento, ângulo etc., enquanto os diretores discutiam a melhor abordagem para aquela entrevista; paralelamente, a equipe de som testava o microfone; e a equipe de produção providenciava as autorizações de imagem, cafés para diminuir o frio (a maior parte das filmagens foram feitas em externa, e os dias estavam bastante frios). Os entrevistados tinham sido previamente contatados e os horários de suas entrevistas marcados com antecedência pela equipa de produção e pesquisa de campo. Ou seja, estávamos realizando um trabalho bem próximo do que acontece numa equipe de filmagem realmente profissional e ao perceberem este fato os alunos sentiam-se mais responsáveis e “donos" de suas funções.

A coordenadora sempre presente, no papel de alguém que estava ali para ajudar, para colaborar, tentava ter uma função como todas as outras da equipe, mas o papel da coordenadora significava para aqueles rapazes muito mais... Era um referencial, um apoio, o ponto forte, onde todas as equipas se reportavam, questionando, e iam alimentar a imaginação, recarregar a inspiração.

Era notória a necessidade de orientação daqueles jovens. No segundo dia de filmagem, quando as coisas corriam lindamente, os alunos já dominavam o processo de realização do vídeo, já tínhamos dado uma diretriz ao conteúdo e à narrativa do filme, e a dinâmica de filmagem realizava-se com muita desenvoltura. A coordenadora teve que ir receber a equipa do programa PICA da RTP2 (canal de televisão público português) no portão principal da escola, no lado oposto onde aconteciam as filmagens. $\mathrm{O}$ caos quase instaurou-se entre os alunos, era como se nunca tivessem feito aquilo, não sabiam o que fazer, o que pensar, perderam uma fita de filmagem e o "fio da meada" - pareciam crianças em pânico. Mas quando a investigadora retornou, sua simples presença fez com que voltassem a se sentir seguros e capazes. Um aluno, quando a coordenadora retornou, chegou a confessar: "Ficamos perdidos sem a presença da Raquel."

Entre acordos, conversas, prioridades, desejos, dúvidas e certezas, aqueles jovens foram dando forma e vida à experiência de fazer um vídeo. Um documentário pensado, realizado e protagonizado por eles. Dois dias de filmagem correram sem maiores problemas dentro do espaço escolar.

Com pouca noção de enquadramento, ângulos, "traquejos" para a montagem, imagens que deviam captar, aqueles rapazes seguiram por um caminho que não sabiam muito bem aonde ia dar. O fazer em si já lhes proporcionava um enorme prazer.

Na entrevista final, quando perguntamos a cada um deles o que tinha achado mais importante de tudo que havíamos trabalhado, ouvimos as seguintes respostas: 
Foi a união, o espírito de trabalho. (Samuel)

A maneira como falamos com as pessoas, para elas compreenderem o que a gente fala. (Manuel)

As opiniões que todos deram. (Vasco)

Nós nos sentimos responsáveis, úteis para alguma coisa. Nos deram importância e responsabilidade. Sentimos que tinha um papel importante no trabalho. Quando soubemos que íamos aparecer na televisão, todos deram o máximo de si. (Jorge)

Discutir com outras pessoas os temas, dar as minhas opiniões. (António).

Foi a cooperação e a vontade de fazer o vídeo em si. (Cristiano)

Foram as discussões que tivemos na sala para fazer o roteiro. (Nuno).

O fundamental é o conteúdo do vídeo, foi o mais importante . (Julio).

Seleção das pessoas para fazer as entrevistas. (Paulo)

O espírito de grupo que foi criado para a realização do trabalho. (Francisco)

A maneira como trabalhamos em conjunto, as ideias que tivemos. (Bruno)

Unir mais a turma; antes do projeto faltávamos muito e durante o projeto não, estávamos todos juntos. Passamos muito tempo juntos, mas é na aula, e não temos tempo para conversar e nos conhecermos mais. (Pedro)

Foi mesmo a opinião das outras pessoas, os depoimentos no vídeo. (José). (CUNHA, 2009, p. 176)

De uma maneira geral, todos os alunos se envolveram com o projeto, uns mais, outros menos, mas este envolvimento teve muito mais a ver com a postura de cada um deles diante da vida, do mundo, suas personalidades e experiências de vida. Em alguns alunos percebíamos que havia o desejo de querer dar mais de si, mas não sabiam como, não se sentiam capazes para fazê-lo, enquanto outros faziam as coisas com uma grande "facilidade". Os mais fracos e os mais fortes; os mais bem preparados e os menos preparados; os mais esclarecidos e os menos esclarecidos - enfim, tínhamos um grupo onde cada um tinha suas limitações, uns mais, outros menos, uns numa área, outros em outra.

Eram pessoas diferentes e com o projeto começaram a se conhecer melhor e a expor seus pontos de vista, ideias e características que alguns, às vezes, no convívio diário habitual da escola, gostariam de esconder. Foi desenvolvido durante o processo do projeto um respeito mútuo, pelo sujeito, pelo outro, e assim tornou-se menos complicado o trabalho em equipe.

No terceiro e último dia de filmagem, quando saímos do território escolar, fomos a dois diferentes bairros dos dois meninos brancos. Era uma equipa reduzida de cinco pessoas e fomos filmar nos bairros sociais, onde moravam os dois alunos.

O consumo de drogas durante os intervalos das aulas ou nos horários livres era algo que já sabíamos que existia desde que começamos a conhecer melhor os alunos. Mas no tempo livre e durante o horário em que não estão na escola fumar ganza (maconha), para alguns daqueles jovens, é como fumar cigarro, algo que fazem com muita naturalidade e assiduidade. E durante os três dias de filmagem esse hábito não mudou; percebíamos que o rendimento de alguns caía consideravelmente durante o tempo que estavam “chapados”. Nas gravações em externa alguns alunos fizeram questão de falar sobre esse hábito e se 
deixaram filmar consumindo a droga. Fora da escola, a ganza parecia ser um ponto de apoio, de reunião, algo que alguns daqueles jovens tinham em comum e faziam questão de exaltar e exibir.

Com certeza a presença da droga foi o fato que mais marcou nossa filmagem no exterior. Como a nossa intenção era deixá-los o mais à vontade possível para serem de fato quem eles eram, no sentido de autenticidade de atitudes, deixamos de lado a hipótese de censurá-los. Os espaços que escolheram para filmar ou para usar drogas eram espaços conhecidos por eles, considerados "seu lugar".

$\mathrm{Na}$ filmagem no exterior, sentimos que os alunos estavam mais relaxados, mostravam-se como eram de fato. A ausência da censura dos professores e funcionários da escola era substituída pelo crivo social. Um exemplo foi no restaurante onde estávamos a almoçar. A pesquisadora estava com a equipe de rapazes (alunos) e mais um entrevistado (que era um jovem considerado "à margem”, pois tinha 19 anos e já tinha uma filha, usava drogas e às vezes "tirava" algumas coisas para ter dinheiro para viver) em um restaurante na zona de um dos alunos e deste entrevistado (que eram amigos). Um dos alunos, então, virou-se e disse:

A senhora [que servia nossa mesa] está a estranhar o que tantos jovens devem estar a fazer junto aqui com a Raquel a almoçar... Deve estar a achar estranho...

O aluno não estava a exagerar, os olhares à nossa volta eram de fato de muita curiosidade. Qualquer movimentação envolvendo os jovens é normalmente vista com grande desconfiança, principalmente quando não são jovens de classe média ou alta; quando envolve os negros então a desconfiança é redobrada.
A edição do vídeo foi feita na "ilha" da Universidade Nova de Lisboa. Fizemos um esquema de modo que os alunos da equipa de edição, som e os diretores fossem até lá para editarmos o material captado. Mas estar tão fora dos seus habitats não estava nos planos daqueles jovens acostumados a ambientes normalmente "familiares" ou conhecidos. A parte mais difícil do projeto foi sem dúvida a edição - não que a edição normalmente seja uma etapa fácil, mas neste caso ela foi de todo o processo a etapa mais difícil. A primeira vez que foram à universidade os alunos estavam constrangidos, inseguros, sentiam-se "peixes fora d'água”. E nada que fazíamos melhorava aquela situação. Os alunos foram abandonando o projeto, não respondiam mais aos e-mails, não mandavam mais mensagens.... Era como se o projeto tivesse terminado no último dia de filmagem. Nas duas últimas semanas de edição só restou um aluno, que praticamente fez a edição quase toda sozinho, com a presença apenas da coordenadora. $\mathrm{Na}$ verdade, Rafael, durante as duas últimas semanas de edição, já não queria mais ir à escola e abandonou-a definitivamente com a finalização do filme (este jovem só voltou na PM no dia da exibição do documentário).

Finalmente chegou o dia de exibirmos o vídeo. Os alunos estavam pontualmente na sala de audiovisual da escola; educadamente foram chegando, nos cumprimentando e em silêncio foram ocupando seus lugares. A expectativa era geral: todos estavam ansiosos para assistir ao filme e também para ver a reação dos outros alunos da escola que também estariam lá, na exibição. Cartazes e convites foram espalhados pela escola para que todos estivessem presentes naquele momento tão importante, onde os alunos (pelo menos alguns deles) da PM, no conceito mais ampliado da expressão, "iriam ter voz". 


\section{Referências}

ADORNO, T.; HORKHEIMER, M. Dialéctica do esclarecimento. Rio de Janeiro: Jorge Zahar Editor, 1985.

BUCKINGHAM, D.; BLOCK, L. de. Finding a global voice? Migrant children, new media and the limits of empowerment. In: DAHLGREN, P. Young citizens and new media: learning for democratic participation. New York: Routledge, 2007. p. 147-163.

CUNHA, R. P. Jovens, media e estereótipos: diário de campo numa escola dita problemática. Lisboa: Livros Horizonte, 2009.

FREIRE, P. Pedagogia do oprimido. São Paulo: Paz e Terra, 2006.

OROFINO, M. I. Mídias e mediação escolar: pedagogia dos meios, participação e visibilidade. São Paulo: Cortez, 2005.

PAIS, J. M. Culturas juvenis. Lisboa: Imprensa Nacional; Casa da Moeda, 2003.

Enviado em: 04/09/2011

Aceito em: 19/12/2011 